\title{
ВИЗНАЧЕННЯ ЦИКЛІЧНИХ ЗАЛЕЖНОСТЕЙ В ЕКОНОМІЦ УКРАЇНИ НА ОСНОВІ АНАЛІЗУ ОКРЕМИХ МАКРОЕКОНОМІЧНИХ ПОКАЗНИКІВ
}

\section{ОПРЕДЕЛЕНИЕ ЦИКЛИЧЕСКИХ ЗАВИСИМОСТЕЙ В ЭКОНОМИКЕ УКРАИНЫ НА ОСНОВЕ АНАЛИЗА ОТДЕЛЬНЫХ МАКРОЭКОНОМИЧЕСКИХ ПОКАЗАТЕЛЕЙ}

\section{THE DETERMINATION OF THE CYCLIC DEPENDENCIES IN THE ECONOMY OF UKRAINE BASED ON THE ANALYSIS OF SOME MACROECONOMIC INDICATORS}

У статті проаналізовано основні причини невміння керівників підприємств передбачати економічні кризи, а також причини скорочення численності підприємств під час економічної кризи. Підкреслена актуальність виокремлення спрощених показників маркетингового середовища, легких і доступних для керівників підприємств, щчо надавало б керівникам можливість ідентифікувати початок $і$ закінчення кризових явищ в економічі краӥни. У статті проаналізований поточний стан економіки Украӥни та висунута гіпотеза про передумови початку нового етапу економіки в Україні. Проаналізовано доцільність для ичих умов використання деяких макроекономічних показників. Проведено порівняльний аналіз динаміки різних макроекономічних показників під час економічних криз в Україні, зокрема динаміки темпу зміни ВВП та динаміки темпу зміни обсягу роздрібного товарообігу. Розглянуто способи виокремлення для украӥнської економіки періодів економічних криз. Розроблені практичні рекомендації для керівників підприємств із використання макроекономічних показників для передбачення моменту настання $i$ закінчення чергових економічних криз в Украӥні.

Ключові слова: економічні цикли, економічна криза, теорія циклів, ВВП, перехідна економіка

B статье проанализировань основные причинь неумения руководителей предприятий предвидеть экономические кризисы, а также причины сокращееия численности предприятий за период экономического кризиса. Подчеркнута актуальность выделения упрощенных показателей маркетинговой среды, легких и доступных для понимания руководителями предприятий, что предоставляло б руководителям возможность идентифицировать начало и окончание кризисных явлений в экономике страны. В статье проанализировано текущее состояние экономики Украины и выдвинута гипотеза существования предпосылок $\kappa$ началу нового этапа экономики в Украине. Проанализирована целесообразность применения в этих условиях отдельных макроэкономических показателей. Проведен сравнительный анализ динамики разных макроэкономических показателей во время экономических кризисов в Украине, в частности динамики темпа изменений ВВП и динамики темпа изменений объема розничной торговли. Рассмотрены способы выделения для украинской экономики периодов экономических кризисов. Разработаны практические рекомендащии для руководителей 
предприятий по применению макроэкономических показателей для предвидения момента наступления и завершения следующих экономических кризисов в Украине.

Ключевые слова: экономические циклы, экономический кризис, теория циклов, ВВП, переходная экономика

In the article the main reasons of the reduction in the number of Ukrainian enterprises during the economic crisis in Ukraine and the failure of the managers of enterprises to predict the future were analyzed. The actuality of simple indicators of the marketing environment, which are easy for understanding for managers and can help them to indicate the onset and the completion of the economic crisis in Ukraine, was highlighted. The current state of the Ukrainian economy was analyzed in the article. The hypothesis of new phase of the economy of Ukraine was proposed in the article. The advisability of the usage of some macroeconomic indicators was analyzed. The comparative analysis of dynamics of various macroeconomic indicators during the economic crisis in Ukraine was conducted, namely the analysis of the dynamics of the rate of change of GDP and the analysis of the dynamics of the rate of change in the volume of the retail trade turnover. The methods of allocation of the periods of the economic crisis for the Ukrainian economy were reviewed. The practical recommendations for managers for the practical application of macroeconomic indicators for economic forecasting the occurrence of the next economic crisis in Ukraine were proposed. economy

Key words: economic cycles, economic crisis, theory of cycles, GDP, transitional

Вступ. Надання Україні статусу країни 3 ринковою економікою означало визнання української економіки як такої, що функціонує за капіталістичними законами ринку. Однак слід враховувати, що остаточне усвідомлення жорстких правил капіталізму до українського підприємництва прийшло не з моменту отримання Україною незалежності у 1991 році та обрання стратегічного курсу розвитку, спрямованого на побудову ринкової економіки, а лише з настанням третьої в історії України економічної кризи 2008 р. Але економічні кризи є невід'ємною складовою будь-якого капіталістичного суспільства. Настання криз $є$ прогнозованим і неминучим явищем ринкової економіки, що докладно описує як теорія економічного розвитку, так і теорія циклів Й. Шумпетера [1], в якій ціле число циклів Дж. Кітчіна (3-5 років) узагальнюється циклами К. Жюгляра (7-11 років), а ціле число циклів К. Жюгляра узагальнюється за допомогою довгострокових циклів Н. Кондрат'єва (42-66 років), також існують економічні цикли С. Кузнеця (15-25 років).

Однак, як на практиці показала історія українського підприємництва, керівники вітчизняних підприємств виявилися ані теоретично, ані практично неготовими до циклічності кризових явищ в Україні. Про такі песимістичні висновки свідчить не тільки стрімке зростання в Україні ринку кредитування у період 2005-2007 pp., що став передкризовим. Адже це наочно продемонструвало хибність прийнятих керівниками підприємств 
управлінських рішень через тодішню їх повну впевненість у власній спроможності у майбутньому віддати взяті кредити, а настання економічної кризи ніхто з них тоді не передбачав. Такі висновки можна також зробити і 3 наслідків подібних помилкових управлінських рішень: за період 2008-2014 pp. кількість суб'єктів господарювання в Україні скоротилася майже у три рази: 3 біля 5,72 млн одиниць (без урахування банків і бюджетних установ) у 2008 році до 1,72 млн у 2013 р. (без урахування банків і бюджетних установ) [2; 13].

Скорочення розміру українського підприємництва через кризові явища має в своїй основі проблему відсутності провадження на підприємствах маркетингової діяльності, метою якої і $є$ налагодження стійкого розвитку підприємств, забезпечення незалежності підприємств від кризових явищ в економіці [17]. Адже результати маркетингових досліджень, основного інструмента маркетингової діяльності, надають можливість маркетологам передбачати майбутні тенденції розвитку ринків і розробляти на основі цього відповідний антикризовий маркетинг-план, який адаптує комерційну діяльність підприємства до умов кризи. Завдяки такому управлінню діяльністю підприємств на засадах маркетингу сплески в економіці не повинні впливати на стійке зростання економічних показників підприємства. Але, поперше, на початку кризи в Україні відбулося масове скорочення на підприємствах маркетологів, а, по-друге, далеко не кожний український суб'єкт господарювання міг економічно дозволити собі мати в штаті маркетолога. Це говорить об актуальності та важливості надання керівникам українських підприємств спрощеного і доступного інструменту передбачення наступних хвиль кризових явищ.

Можна виокремити декілька факторів маркетингового середовища, показники яких надають можливість вчасно передбачати настання економічної кризи, а саме: кількість інвесторів і обсяг інвестицій в економіку; масове застосування підприємствами країни концепції інтенсифікації комерційних зусиль [3] і темп зміни ВВП [1; 12]. Так, кількість інвесторів і обсяг їх інвестицій у кризовій країні досягають свого максимуму далеко не у перший рік кризи, а коли самооцінка інноваторів і їх інноваційних проектів впаде максимально. Тому пікові значення у динаміці показників цих критеріїв слід інтерпретувати як показники початку і закінчення кризи, а іiі спадаючий чи зростаючий річний тренд - відповідно ознаками наближення кризи чи подолання економікою «дна» [3]. Досить чутливим до настання кризових явищ $\mathrm{i}$ одночасно простим у використанні підприємствами $\epsilon$ показник застосування суб’єктами ринку концепції інтенсифікації комерційних зусиль. Історичний аналіз демонструє, що масовий перехід підприємств до цієї концепції управління ставала характерною ознакою і передумовою початку економічних криз [3]. Це можна пояснити тим, що концепція інтенсифікації 
комерційних зусиль, згідно якій споживачі купуватимуть ті товари та послуги, що активно стимулюються i рекламуються, стає відповідними діями підприємств на перегрів економіки та моменту насичення попиту на ринку. При цьому до найбільш популярного і доступного для підприємств показника, що оцінює стан економіки, відноситься динаміка зміни валового внутрішнього продукту (ВВП), оскільки основними наслідками економічної кризи стають зниження рівня зайнятості через зниження обсягу виробництва $[1 ; 12]$.

Дослідженню економічних циклів, питанням оцінювання i прогнозування розвитку економіки України присвячені роботи багатьох авторів. Серед них особливої уваги, 3 нашої точки зору, заслуговують результати досліджень Й. А. Шумпетера [1], С. В. Войтка [4; 5], В. Г. Герасимчука [6], П. В. Круша [7], Ю. М. Харазішвілі [8], Т. В. Саколоша [6], Н. В. Сопрун [5]. Більшість висновків цих робіт грунтується на результатах вивчення динаміки різних макроекономічних показників економіки, у тому числі і темпів зміни ВВП України. Проте залишається чимало нерозв'язаних питань переважно практичного характеру. Зокрема немає єдиного підходу до визначення ознак початку та кінця економічної кризи. При цьому для більшості керівників українських підприємств $є$ принципово важливим не тільки вміти вчасно усвідомити процеси наближення і закінчення економічної кризи у країні, щоб адекватно відкоригувати діяльність власного підприємства, але й вміти прогнозувати настання кризових явищ у майбутньому.

Постановка завдання. Головною метою статті $\epsilon$ виокремлення спрощеної системи показників маркетингового середовища, які нададуть можливість власникам українських підприємств самостійно ідентифікувати, передбачати та окреслювати часові межі економічних криз і вчасно реагувати на це шляхом запровадження відповідних управлінських рішень.

Методологія. Методологічну основу дослідження формують концептуальні підходи з вивчення циклічності розвитку економічних систем, системний підхід до аналізу умов протікання та причинно-наслідкових зв'язків економічних криз в Україні. У дослідженні використані методи системного та порівняльного аналізу, теоретичного узагальнення, метод історичних аналогій, екстраполяції аналізу статистичної інформації.

Результати дослідження. Проведений нами аналіз джерел статистичної інформації надав можливість виокремити декілька основних причин, якими можна пояснити відсутність єдиних підходів до виокремлення кризових явищ в Україні. По-перше, це пов'язано 3 неоднозначною оцінкою динаміки показнику ВВП України. Не виключено, що руйнація на початку 1990х років 
централізованої економічної системи надала певні похибки при перерахунках економічних показників для новонародженої України. Подібні похибки зростають через наявність «тіньової» частини ВВП, що на різних етапах історичного розвитку України суттєво занижували значення ВВП. Наприклад, у період 2010-2014 рр. тіньовий ВВП України коливався на рівні біля 500 млрд грн, що складало біля 35-41 \% від динаміки ВВП у цей період (рис. 1) [8].
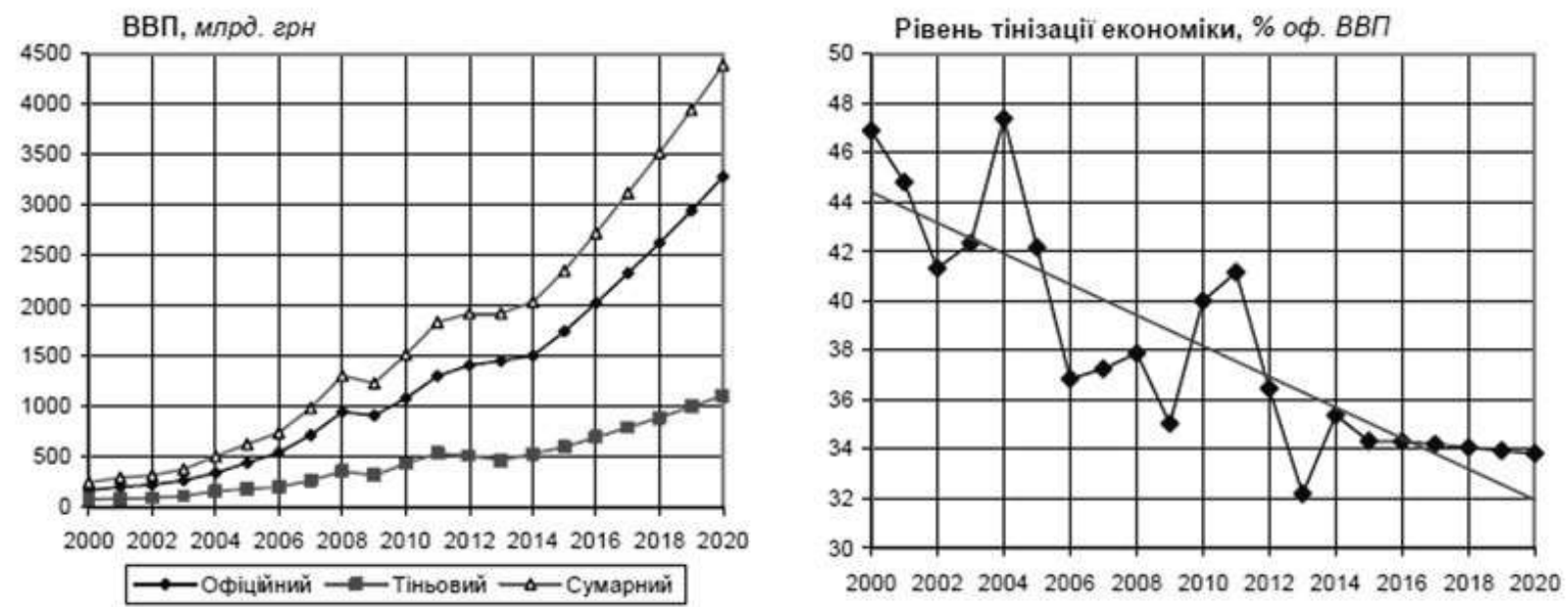

Рис. 1. Динаміка тіньового ВВП та рівня тінізації економіки України (* 2016-2020 прогнозні значення) [8]

По-друге, оцінювання динаміки темпів зміни ВВП ускладнюється високою залежністю нестабільної національної валюти (карбованців, купонів, гривень) від курсу долару. По-третє, методика розрахунку змін ВВП не $\epsilon$ однозначною. Згідно загальноприйнятим визначенням, яким користується більшість підприємств, під зміною ВВП слід розуміти відношення величини зміни показника ВВП у поточному році до його рівня у попередньому періоді. Однак, порівняння офіційно опублікованих на сайті Державної служби статистики України показників темпу зміни ВВП і розрахованих показників темпу зміни ВВП у відповідних роках не завжди узгоджуються між собою. Крім того, значення як номінального, так і реального обсягу ВВП не $\epsilon$ однаковим у різних джерелах інформації, доступних для керівників підприємств. Особливо це стосується періоду перехідної економіки України 1991-2006 рр. Зокрема, не узгоджується між собою обсяг ВВП у доларах США, у поточних цінах, опублікований на порталах Міжнародного валютного фонду [9] та Групи Всесвітнього банку [18], у той час як на сайті Державної служби статистики України [13] ця інформація за період 1991-2006 рр. 3 кінця 2015 року узагалі стала недоступною. Це може викликати відповідні непорозуміння з боку підприємців. Наприклад, на офіційному сайті Державної служби статистики України на сторінці Консультаційного центру серед 
найбільш розповсюджених питань опубліковано прохання одного 3 користувачів роз'яснити методику розрахунку темпу зміни ВВП і відповідь Державної служби статистики України (рис. 2). Це свідчить про неодноразові запити і високу актуальність роз'яснення цієї методики для користувачів сервісу.

\section{СТАТИСТИЧНА МЕТОДОЛОГІЯ}

Bcboro: $6 \quad 1$ - 10 Показуеати по 10 .

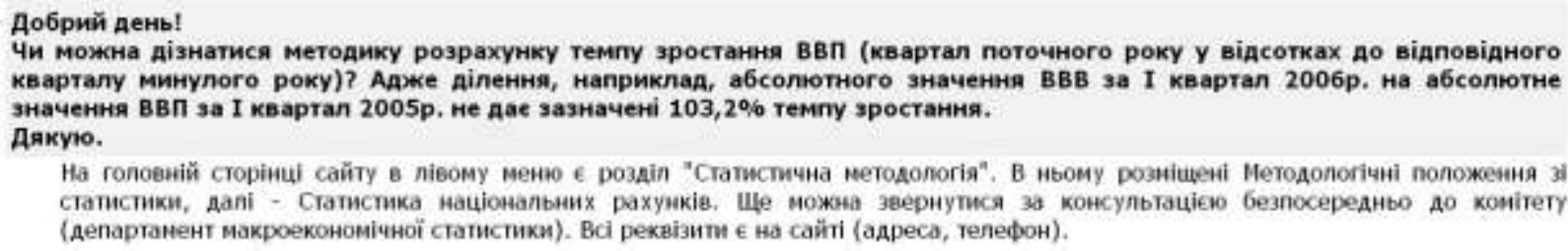

На головній сторінці сайту в півому меню $€$ роздіп "Статистина методопогія". В ньому розніщені Нетодологієні положення зі статистики, далі - Статистика національних рахуиків, Ще можна звернутися за консультацією безпосередньо до комітетү (департанент макроекономічної статистики). Всі реквізити є на сайті (адреса, телефон).

Рис. 2. Зображення з екрану сторінки Консультаційного центру на сайті Державної служби статистики України [13]

Відповідь Державної служби статистики України посилається на «Методологічні положення оновленої версії системи національних рахунків 2008 року» (Наказ Державної служби статистики України від 17.12.2013 р. № 398), що 32013 р. були змінені відповідно 3 оновленими міжнародними стандартами СНР-2008. Вони стосувалися зміни методик розрахунку умовно обчислених послуг фінансового посередництва (УОПФП), обчислення послуг страхування, включення результатів наукових досліджень і видатків на озброєння до складу валового нагромадження, зміни відображення операцій із зовнішньої торгівлі товарами для перероблення, включення до сфери виробництва нелегальних видів економічної діяльності, зміни методики обчислення послуг із проживання у власному житлі, що відобразилося на динаміці як власне обсягу ВВП, так і відповідно на динаміці темпів його зміни [10]. Крім того, запровадження нової версії класифікації видів економічної діяльності КВЕД-2010 вплинули на уточнення визначень i правил класифікації одиниць, які передають виробництво своєї продукції іншому виконавцю (аутсорсингу), що так само вплинуло на методику розрахунку темпу зміни ВВП. Такі перерахунки є важливим і необхідним кроком, але вони ускладнюють розуміння сутності темпу зміни ВВП для більшості пересічних керівників підприємств.

У більшості розвинених країн світу темп зміни ВВП розраховується за допомогою так званого ланцюгового (істинного) індексу, і при розрахунку темпу зміни у поточному році у якості базового року обирається попередній рік [11]. При нерівномірному зростанні за секторами економіки темп зміни ВВП розраховується як середньозважене темпів зміни виробництва окремих 
товарів і послуг. Наприклад, на рис. 3 показана динаміка темпу зміни ВВП США.

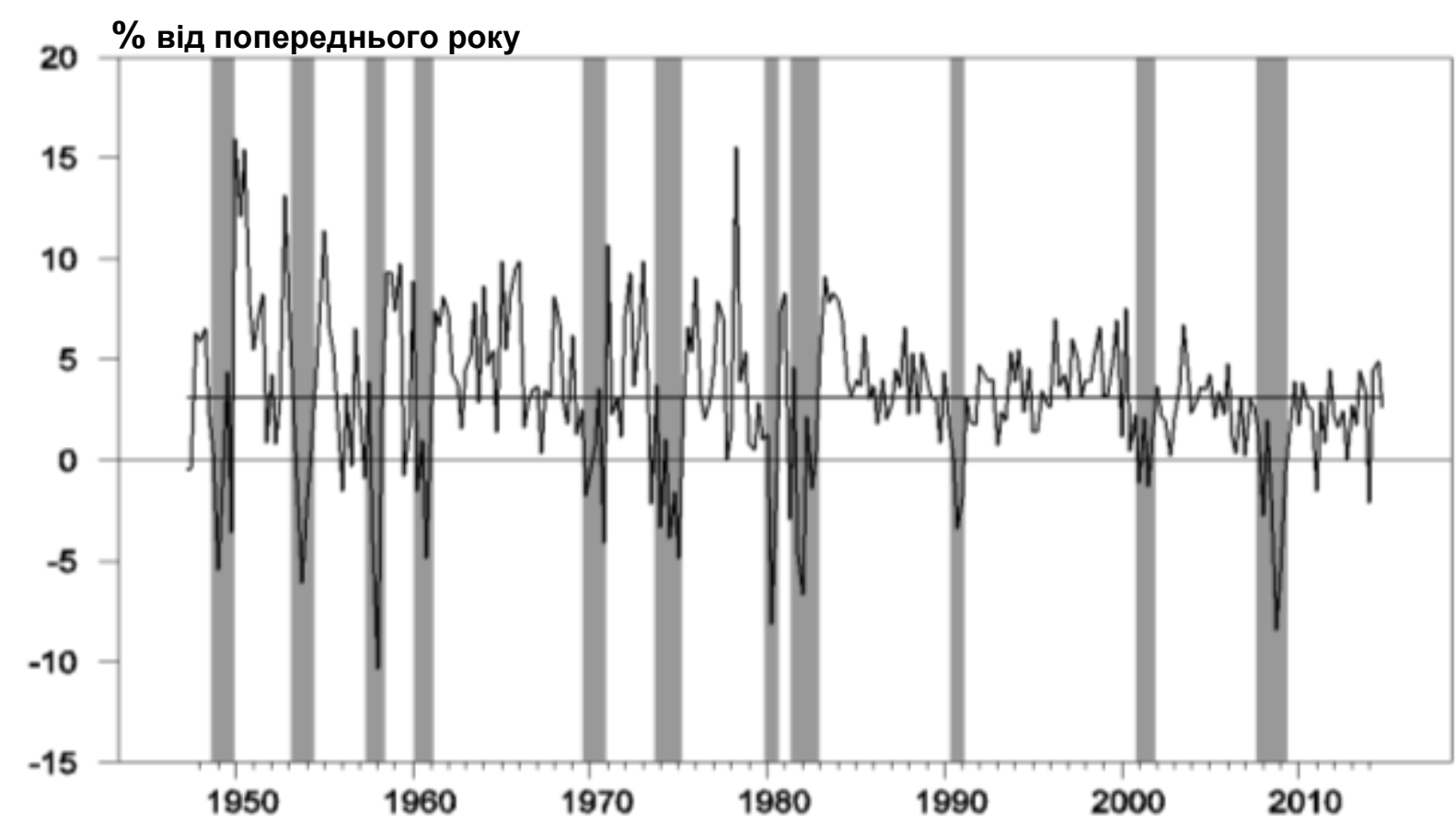

Рис. 3. Темп зміни ВВП США (у \% від попереднього року) [12].

Сірим кольором виокремленні періоди офіційно визнаних США економічних криз [12]. Можна помітити, що більшість «сірих зон» збігаються із динамікою зміни ВВП, яка у ці періоди опускалася нижче історичного середнього значення для США - 3,1 \% (горизонтальна лінія на рис. 3). На рис. 4 представлена для української економіки порівняльні динаміки аналогічного показника темпу зміни ВВП (у \% від попереднього року), розрахованого на основі показнику ВВП у гривнях (до 1995 р. - у карбованцях) та у доларах, а також лінія його середнього історичного значення (-1,18\%).

Як бачимо, застосування середнього історичного значення темпу зміни ВВП у якості показника економічної кризи в України є досить суперечливим, особливо для періоду 1991-98 рр. Якщо спиратися на історичне середнє значення офіційних темпів зміни ВВП у національній валюті (див. рис. 4), то можна зробити висновок, що в Україні криза 1991-го року тривала майже до початку 1998 року, а з 1998-го року в Україні почалося зростання, що не зовсім відповідає дійсності. 


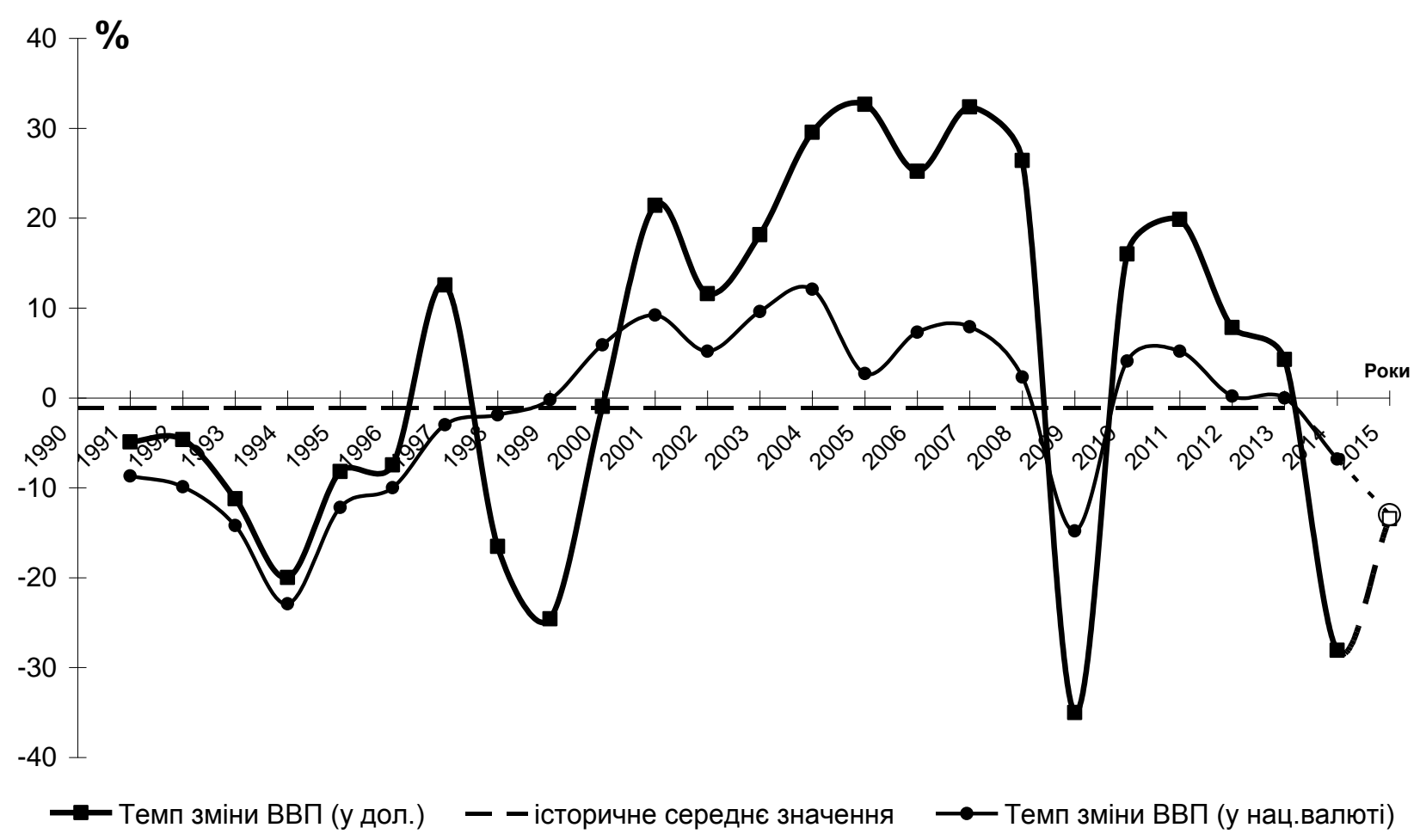

Рис. 4. Порівняння динаміки темпу зміни ВВП України (у національній валюті) із динамікою темпу зміни ВВП України (у доларах США, у поточних цінах, \% від попереднього року). (Складено автором на підставі досліджень $[9 ; 13-15 ; 18])$

Виходячи з історичних реалій української економіки, можна висунути гіпотезу, що більш чутливим показником економічної кризи для України може стати спрямованість зміни ВВП. Згідно такому підходу вихід з кризи, що розпочалася у 1991-му році, почався у 1995 році, коли темп зміни ВВП продемонстрував зростання. При цьому тренди, побудовані на основі значень ВВП у різних валютах, відрізняються один від одного. Можна побачити, що більш адекватною виявляється динаміка темпу зміни ВВП, вираженого у доларах США, у поточних цінах, у відсотках від попереднього року (суцільний тренд на рис. 4). Однак, у 2002 р. і у 2006 р. темп зміни ВВП знаходився у спадаючому тренді, коли кризи ще офіційно не було (хоча таке незначне падіння ВВП можна пояснити циклами Дж. Кітчіни). Тому подібні часткові випадки погіршують застосування керівниками українських підприємств темпу зміни ВВП у якості показника, чутливого до економічних криз в Україні у цей історичний період.

Існує багато різноманітних підходів до пояснення причин економічних криз, наслідком чого стають зниження рівня зайнятості та виробництва. При цьому більшість причин економічних криз у ринковій економіці призводить до іï «перегріву» через те, що сукупна пропозиція починає обганяти сукупний 
попит. 3 одного боку, економічна криза 1991-го року в Україні має певні неузгодженості з подібним підходом, оскільки при існуючому попиті вона була пов'язана не 3 перебільшеним обсягом пропозиції, а навпаки - 3 дефіцитом. Тому економіка України періоду 1991-2006 pp. увійшла в історію як перехідна. Статус країни з ринковою економікою Україна отримала від СС тільки у грудні 2005 р., а від США - у лютому 2006 р. Це надає можливість у подальшому розгляді, починаючи 32007 року, адекватно застосовувати динаміку темпу зміни ВВП як критерію ознаки кризи української економіки.

3 іншого боку, темп зміни ВВП характеризує лише існуючий на ринку рівень пропозиції, оскільки цей показник відображає ринкову вартість усіх кінцевих товарів і послуг (передбачених для споживання), що вироблені протягом року в усіх галузях економіки на території держави для споживання, експорту i накопичення, незалежно від національної приналежності використаних факторів виробництва [15]. Таким чином, для більш чіткого обмеження періоду економічної кризи для керівників підприємств потрібен ще додатковий простий показник маркетингового середовища, який би оцінював рівень існуючого в країні попиту.

Попередньо нами були графічно побудовані динаміки різних показників економіки України, які спроможні оцінити попит, та порівняли їх із періодами економічних криз в Україні. У результаті такого дослідження найбільш чутливим показником до кризових етапів в Україні виявився темп зміни роздрібного товарообігу. Наведена на рис. 5 динаміка запропонованого показника демонструє поведінку кінцевих споживачів. За темпом зміни роздрібного товарообігу можна передбачати темп зміни сукупного попиту в Україні у цілому. Обсяг виробництва товарів і послуг визначає рівень зайнятості i, як наслідок, рівень життя населення країни, що й надає населенню можливість купувати у роздріб. Але на відміну від показника сукупної пропозиції (ВВП), цей оціночний показник надаватиме суттєво меншу похибку завдяки відносно невеликій кількості складових, які зосереджені виключно всередині країни. Тому динаміка поведінки кінцевих споживачів, як фактор маркетингового середовища, може розглядатися керівниками підприємств у якості одного 3 досить чутливих i простих оціночних показників кризових явищ в економіці України. 


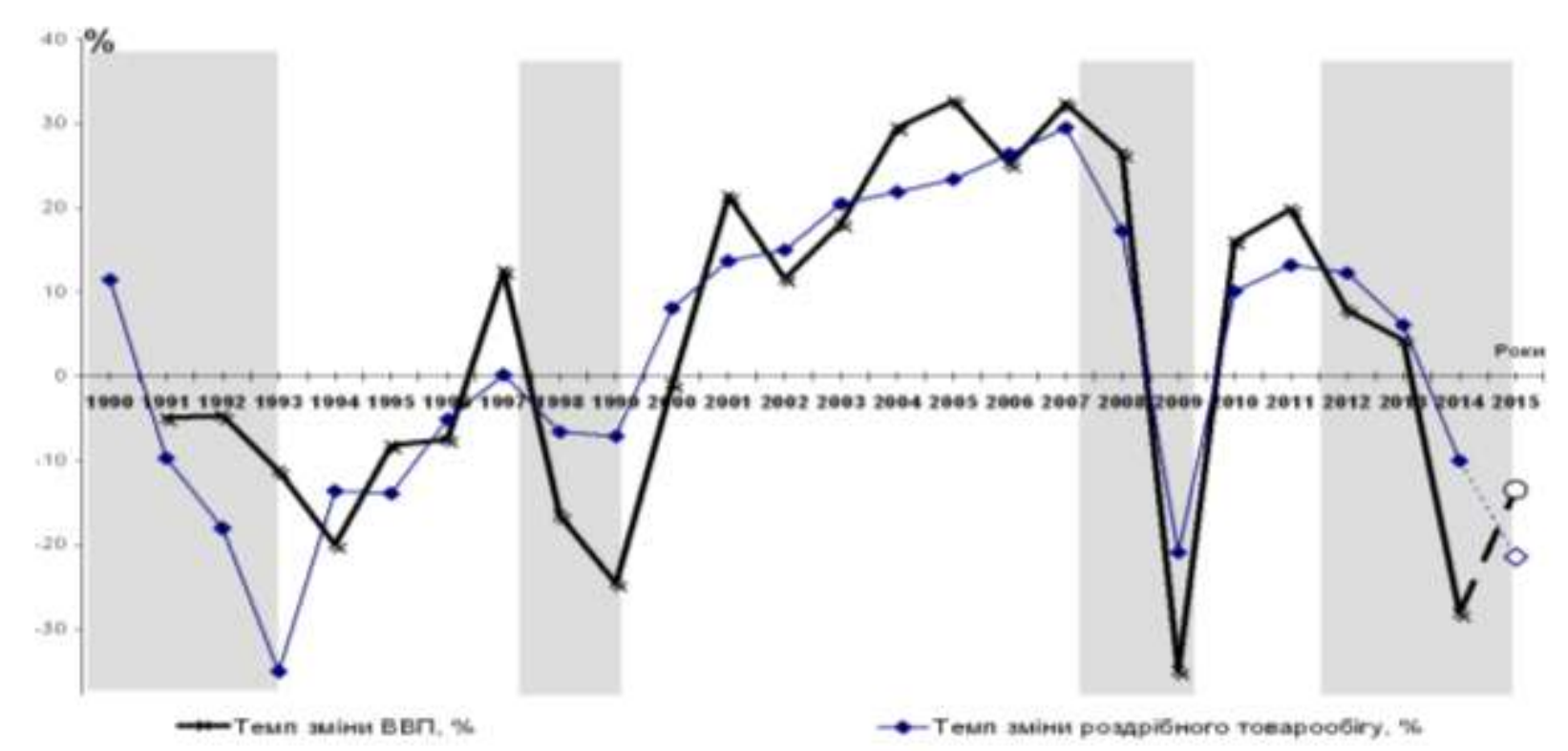

Рис. 5. Порівняння динаміки темпу зміни обсягу роздрібного товарообігу (у національній валюті) України із динамікою темпу зміни ВВП , у поточних цінах, \% від попереднього року) (складено автором на підставі досліджень $[9 ; 13-15 ; 18])$

Так, з рис. 5 можна побачити, що в Україні падаючий тренд роздрібної торгівлі ставав характерною ознакою початку криз, оскільки свідчив про досягання можливого рівня купівельної спроможності кінцевих споживачів (або насичення попиту). Як бачимо, темп зміни обсягу роздрібної торгівлі в Україні демонстрував падаючий тренд у наступні періоди (сірі зони на рис. 5): - 1990-1993 рр. - період першої в історії незалежної України економічної кризи (наголосимо, що для цього періоду слід враховувати необхідність перегляду дати початку цієї кризи та ії переносу на більш ранній період, який передував розпаду СРСР i отримання Україною незалежності. Однак перевірка цього сьогодні буде ускладнена похибками i припущеннями перерахунків статистичних даних цього періоду);

- 1998-1999 рр. - період другої економічної кризи в Україні;

- 2008-2009 pp. - період третьої економічної кризи в Україні;

- у 2012-2015 pp. - період четвертої економічної кризи в Україні.

У цілому динаміка темпу зміни обсягу роздрібного товарообігу узгоджується з офіційними періодами економічних криз в Україні. Таким чином, можемо зробити висновок, що динаміка темпу зміни роздрібного товарообігу може стати більш чутливим показником визнання економічних криз. Оскільки отриманні висновки зроблені на основі історичного досвіду України в умовах перехідної економіки, то вони будуть також корисними у якості аналогії для інших країн світу із перехідною економікою.

Проаналізуємо періодичність кризових явищ в Україні, спираючись на виокремленні вище періоди (див. сірі зони на рис. 5). Як бачимо, період між 
початком перших трьох в історії України кризами коливався у проміжку 7-11 років. Незважаючи на те, що у цей період в Україні ще була перехідна економіка (до 2006 року), періодичність українських криз узгоджувалась 3 тривалістю циклів К. Жюгляра, що у більшому ступені притаманно ринковій економіці. 3 одного боку, деяким виключенням з цієї теорії слід вважати кризу 2012-го року, початок якої відбувся вже через 4 роки після початку кризи 2008-го року. 3 іншого боку, кризу 2012 р можна пояснити тривалістю циклів Дж. Кітчини. Незважаючи на це, криза 2008-го і тим більше криза 2012-го року стали не зовсім очікуваними явищами як на рівні України, так і на рівні глобальної економіки [3; 17]. Для пояснення цього можна висунути дві гіпотези, які не виключають одна одну.

Перша гіпотеза полягає у припущенні, що у наслідок останніх криз економіка України може знову стати перехідною. Слід враховувати події, через які Україна вже третій рік поспіль не контролює виробничі та природні ресурси на Сході і в Криму, що були складовою формування іiі ВВП. Переформування структури ВВП, зміна площі географічної території України, кількості населення, руйнація економічних зв'язків і таке інше мають певні аналогії з розглянутим вище періодом перехідної економіки України початку 1990-х років. Так само, як на початку 1990-х років, Державна служба статистики України вже почала здійснювати відповідні перерахунки статистичних показників без урахування тимчасово окупованої території Автономної Республіки Крим, м. Севастополя та частини зони проведення антитерористичної операції. Такий сьогоднішній перебіг подій, як вище показав аналіз аналогічного історичного періоду в Україні, унеможливлює адекватне застосування динаміки темпу зміни ВВП у якості надійного показнику для прийняття управлінських рішень. Крім того у найближчому періоді вірогідність трансформації ринкової економіки України у перехідну економіку збільшуватиметься завдяки інтеграції України у ЄС. Для перехідної економіки притаманна тимчасова нестабільність, реформування (еволюція до нової економічної системи, до нового врівноваженого стану) [16]. Тому керівники українських підприємств у найближчому періоді так само можуть використовувати запропонований вище критерій темпу зміни роздрібної торгівлі для ідентифікації економічних криз в Україні у майбутньому.

Однак, слід зауважити, що історичний досвід економіки України 19912006 pр., незважаючи на іï перехідний статус, узгоджувався 3 тривалістю економічних циклів 7-10 років, що більш характерно циклам К. Жюгляра для ринкової економіки. Тому більш обгрунтованою може стати друга гіпотеза, яка полягає у припущенні, що економіка України увійшла у «режим iз загостренням». Під «режимом із загостренням» розуміється настання таких періодів, під час яких усі процеси, що оточують Людство у цілому, починають прискорюватися за законом експоненти [17]. Адже при умові відсутності 
режимів із загостреннями початок кризи, наступної після кризи 2008 р., слід було б очікувати не у 2012 році, як це сталося насправді, а лише у період 2015-2018 pp. Тому можна передбачати, що i у подальшому частота економічних криз збільшуватиметься за законом експоненти, що має призвести до відповідного скорочення періодів між економічними кризами. Це надає підприємствам України певний інструмент передбачення моменту настання кризи та підготуватися до неї. Виходячи з такої гіпотези, наступну кризу в Україні слід орієнтовно очікувати вже у 2016 р.

Гіпотезу входження економіки України у режим із загостреннями також підтверджує низка факторів маркетингового середовища, що отримали глобальний характер. По-перше, криза 2008-го року стала кризою глобальної економіки, оскільки початок і поширення економічних криз у більшості країн світу як у 2008-му році, так і у 2012-му році були майже синхронними (рис. 6).

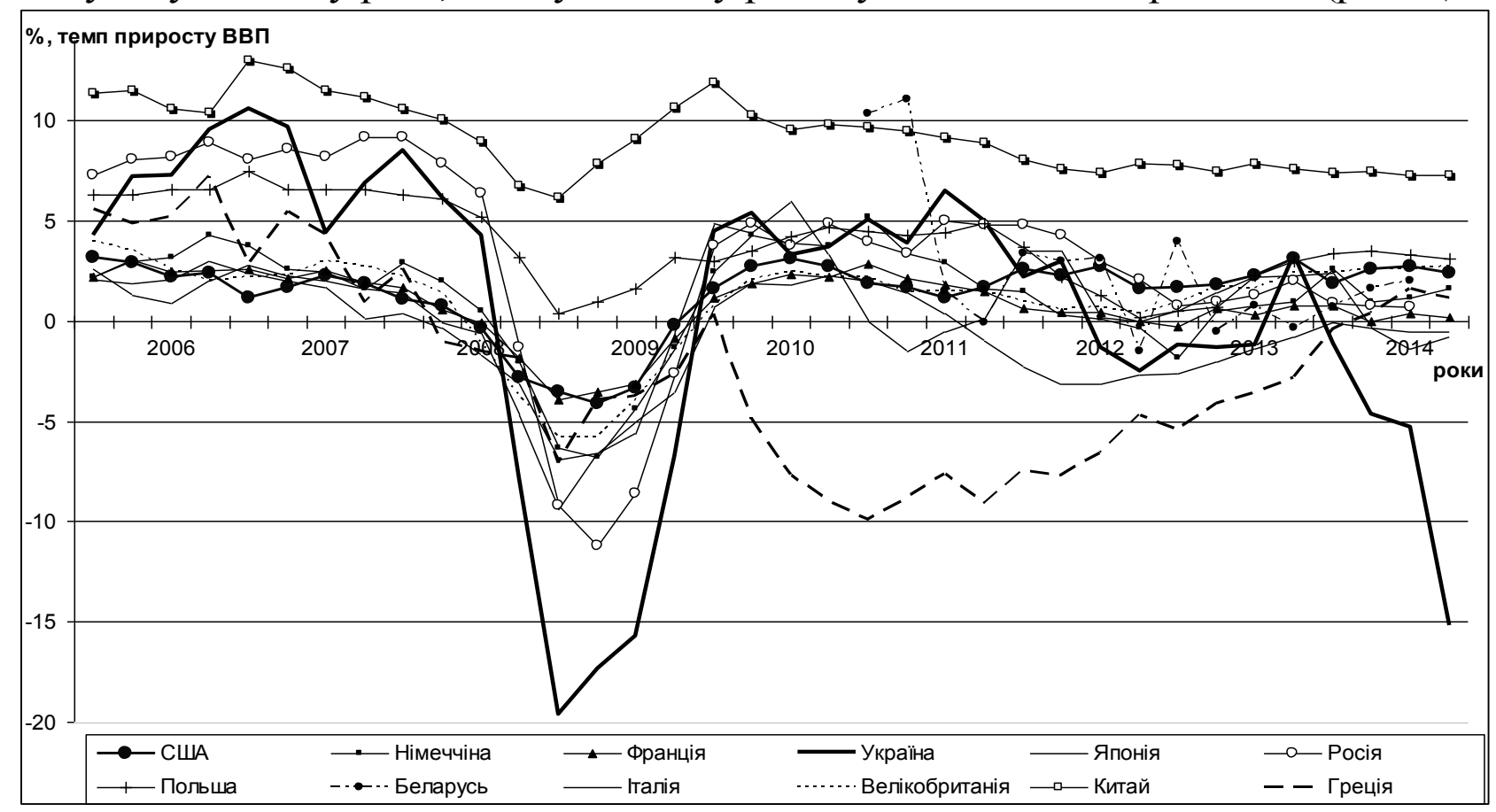

Рис. 6. Порівняння динаміки темпів щоквартальної зміни ВВП України 3 іншими країнами світу, у \% до попереднього періоду (у доларах США) (за даними $[14 ; 19])$

Хоча майже синхронна криза 2012 року для більшості країн світу не стала настільки потужної (за виключенням України), як криза 2008 р., глобальність ii характеру унеможливлює застосування традиційних інструментів, що були ефективними у минулому. Наприклад, не стане інструментом подолання кризи для підприємства, країна якого переживає економічну кризу, вихід на міжнародні ринки інших країн 3 незмінним асортиментом товарів і послуг, якщо ці країни так само переживають схожу економічну кризу. Це потребуватиме глобального антикризового управління або пошуку інноваційних інструментів подолання глобальних криз. 
По-друге, з рис. 6 можна помітити, що синхронне настання економічних криз частішає. Наприклад, зниження темпів зміни ВВП у США починалося у 2005 році, у 2010-му році та у 2012-му році, що продемонструвало послідовне скорочення періодів між двома останніми кризами до 5 та 2 років відповідно. Крім того подібне прискорення періодичності криз «притягує» темпи зміни ВВП більшості розвинених економік світу до коливання навколо відмітки $0 \%$, що можна інтерпретувати як світову тенденцію гальмування глобального економічного розвитку, що потребує пошуку принципово нових інструментів управління підприємствами та глобальною економікою у цілому.

Висновки. Підсумовуючи проведене дослідження, можна сказати наступне. До основної наукової новизни роботи відноситься передбачення настання етапу перехідної економіки України, що викликано наслідками економічної кризи, інтеграцією України в Європейський Союз і відсутністю економічного контролю в Автономній Республіці Крим, м. Севастополі та частині зони проведення антитерористичної операції. На основі проведеного аналізу чутливості макроекономічних показників до кризових явищ в економіці України запропоновано в умовах перехідної економіки i перебільшеної кількості інформації у якості спрощених індикаторів користуватися не тільки динамікою змін ВВП, що характеризує рівень пропозиції на українському ринку, але й також динамікою темпів зміни роздрібного товарообігу, що характеризує рівень попиту. Це надасть можливість керівникам підприємств вчасно відреагувати на зміни економічного стану України та адаптувати до цього свої підприємства. За допомогою дослідження динаміки цього показника для України було обгрунтовано виокремлення чотирьох історичних періодів економічних криз, a саме: 1991-1993 pp., 1998-1999 pp., 2008-2009 pp. і 2012-2015 pp., що відкриває можливість для передбачення моменту настання чергових криз в Україні. Розроблені рекомендації з урахуванням входження кризових явищ в Україні у режими 3 загостреннями надають можливість керівникам скоригувати і завчасно запровадити відповідний комплекс управлінських дій на підприємстві.

Перспективами подальших розробок у даному напрямі є необхідність на рівні окремих підприємств подальшого спостереження за коливаннями запропонованих показників економічного стану України та практичної перевірки висунутих у цій статті гіпотез і прогнозів на майбутнє.

\section{Література:}

1. Schumpeter J. A. Business cycles: A theoretical, historical and statistical analysis of the capitalist process / J. A. Schumpeter ; abridged, with an introduction, by Rendigs Fels. - New York. ; Toronto ; London : McGraw-Hill Book Company, 1939. - 461 pp.

2. Васильченко О. О. Аналітичний звіт про стан і перспективи розвитку малого та середнього підприємництва в Україні [Електронний ресурс] / О. О. Васильченко // Державна служба України з питань регуляторної політики та розвитку підприємництва. 
$\begin{array}{cccc}2014 . & - & \text { Режим } & \text { доступу }\end{array}$ ahUKEwiBtfCfhKfMAhWBAJoKHR68AVcQFggaMAA\&url=http\%3A\%2F\%2Fwww.dkrp.gov.ua\%2Ffile s\%2F8cd09.docx\&usg=AFQjCNGLPztEZ6Y23v3dBsTJ1Oi8IhzwDw\&bvm=bv.119745492,d.bGs.

3. Юдина Н. В. Антикризисные маркетинговые инструменты инновационного развития предприятий / Н. В. Юдина // Маркетинг и финансы. - 2014. - Т. 1. - С. 60-72.

4. Войтко С. В. Системний підхід до життєвого циклу / С. В. Войтко // Маркетинг: теорія і практика : збірн. наук. праць Східно-укр. держ. ун-тету / ред. кол.: І. Л. Решетнікова (гол. ред.). - Луганськ : Вид-во Східноукр. держ. ун-ту, 1999. - С. 105 - 110.

5. Войтко С. В. Систематизація теоретичних положень та наукових поглядів щодо циклічних процесів у економіці [Електронний ресурс] / С. В. Войтко, Н. В. Сопрун // Ефективна економіка. - 2013. - № 3. - Режим доступу : http://www.economy.nayka.com.ua/?operation=1\&iid=1858.

6. Герасимчук В. Г. Инновационная модель развития экономики в условиях глобализации / В. Г. Герасимчук, Т. В. Сакалош. // Економічний вісник Національного технічного університету України „Київський політехнічний інститут” : збірник наукових праць. 2008. - №5. - С. 79-87.

7. Круш П. В. Механізми економічного управління та регулювання: еволюція, напрями розвитку / П. В. Круш // Економічний вісник НТУУ «КПІ» : збірник наукових праць. 2008. - № 5. - C. 32-36.

8. Харазішвілі Ю. М. Прогнозування індикаторів, порогових значень та рівня економічної безпеки України у середньостроковій перспективі : аналітична доповідь / Ю. М. Харазішвілі, Є. В. Дронь. - К. : НІСД, 2014. - 117 с.

9. World Economic and Financial Surveys World Economic Outlook Database [Електронний pecypc] / "IMF", http://www.imf.org. - 2014. - Режим доступу : http://www.imf.org/external/pubs/ft/weo/2014/02/weodata/index.aspx.

10. Методологічні положення оновленої версії системи національних рахунків 2008 року / Державна служба статистики України, 2013. - 19 с. - Режим доступу : http://www.ukrstat.gov.ua/metod_polog/metod_doc/2013/398/met_polog.zip.

11. Сосунов К. Рост ВВП: отчетность и действительность [Електронний ресурс] / К. Сосунов, Е. Шарипова // Независимая газета, http://www.ng.ru. - 2005. - 19 квітня. Режим доступу : http://www.ng.ru/ideas/2005-04-19/11_rostVVP.html.

12. Hamilton J. Another solid GDP report [Електронний ресурс] / James Hamilton // Econbrowser, http://econbrowser.com.. - 2015. - Режим доступу : http://econbrowser.com/archives/2015/01/another-solid-gdp-report.

13. Статистична інформація [Електронний ресурс] / Державна служба статистики України. - 2016. - Режим доступу : www.ukrstat.gov.ua.

14. Indicators [Електронний pecypc] // Trading Economics. - 1991. - Режим доступу : http://www.tradingeconomics.com.

15. Валовой внутренний продукт Украины [Електронний ресурс] / Финансовый портал "Минфин". - 2016. - Режим доступу до ресурсу: http://index.minfin.com.ua/index/gdp.

16. Аллен Дж. Основы свободного предпринимательства. / Дж. В. Аллен, Д. Дж. Армстронг, Л. С. Уолкен. - К. : УкрНИИНТИ, 1992. - 24 с. - (Экономика : Сер. «Помощь предпринимателю (зарубежный опыт) »; Вып. 3).

17. Юдина Н. В. Предпосылки футурологии в системе образования маркетологов / Н. В. Юдина // Социальная экономика : научный журнал = Social Economics : scientific journal / Харьковский нац. ун-т им. В.Н. Каразина. - Харьков : ХНУ. - 2014. - Вып. 48, № 1-2. C.187-193. - ISSN 2415-2456. 
18. GDP at market prices [Електронний ресурс] / The World Bank, worldbank.org.. - 2016. Режим доступу до ресурсу: http://data.worldbank.org/indicator/NY.GDP.MKTP.CD.

19. Firming global demand to push Asean GDP growth: Moody's / http://www.thestar.com.my. 11 October 2013. - Режим доступу : http://www.thestar.com.my/Business/BusinessNews/2013/10/11/Firming-global-demand-to-push-Asean-GDP-growth-Moodys/?style=biz. 